\title{
Effect of temperature on litter decomposition, soil microbial community structure and biomass in a mixed-wood forest in European Russia
}

\author{
Kravchenko Irina, K.*, Tikhonova Ekaterina, N., Ulanova Ruzalia, V., \\ Menko Ekaterina, V. and Sukhacheva Marina, V. \\ Research Center of Biotechnology of the Russian Academy of Sciences, 33, bld. 2 Leninsky Ave. 19071, Moscow, Russia
}

\begin{abstract}
Litter decomposition in terrestrial ecosystems has a major role in the biogeochemical cycling of biogenic elements, but initial stages of this process in temperate forest ecosystems remain poorly understood. Soil organic matter in forest ecosystems is highly sensitive to temperature rise, which makes it the most vulnerable under global warming. This article assesses the influence of aspen leaf and twig litter on the activity and quantitative characteristics of microbial communities of soils in conditions modelling climate warming. The experiments were performed with samples of grey forest soil, one of the most representative soil types of Europian Russia, from forest biocenosis in the Moscow region. Incubation of soil samples, in which crushed leaves and twigs were added at the rate of $0.5 \%$ by weight, was carried out at constant temperature of $5^{\circ} \mathrm{C}, 15^{\circ} \mathrm{C}$ and $25^{\circ} \mathrm{C}$ for 28 days. $\mathrm{CO}_{2}$ emission, organic carbon and microbial biomass content, and number of ribosomal genes of bacteria, archaea and fungi were evaluated. The optimal temperature for decomposition of the plant litter was found to be $15^{\circ} \mathrm{C}$, and both decrease and increase led to a reduction in the intensity of the degradation process. In the temperature range $5^{\circ} \mathrm{C}-15^{\circ} \mathrm{C}$, application of plant residues led to significant increase in temperature sensitivity of the soil respiration process, and temperature coefficient $Q_{10}$ increased from 1.75 to $3.44-3.54$. At high temperatures, addition of litter stimulated the decomposition of soil organic matter. No significant changes in microbial biomass, bacteria and fungi numbers were observed. The obtained results contribute to understanding the dynamics of soil carbon and can be used in predictive models of plant litter and soil organic matter dynamics in forest biocenoses of Eurasia under climate change.
\end{abstract}

Keywords: Carbon cycling, litter decomposition, microbial respiration, mixed-wood forest, temperature sensitivity.

WoOD litter represents a mixture of organic substances contained in the annually dying plant parts. Litterfall in

*For correspondence. (e-mail: irinakravchenko@inbox.ru) terrestrial ecosystems is of great value for the return of nutrients to the soil and can markedly modify biotic and abiotic conditions on the forest floor, altering soil $\mathrm{C}$ and nutrient cycling. Despite the sufficiently high number of studies on primary productivity of forest communities, transformation of wood litter has not been sufficiently examined and requires detailed analysis. The total wood fall in the Russia is estimated at $35-55$ centre $\mathrm{C} \mathrm{ha}^{-1}$ in the coniferous zone and $65-90$ centre $\mathrm{C} \mathrm{ha}^{-1}$ in deciduous forests with leaf fall of $8-15$ centre $\mathrm{C} \mathrm{ha}^{-1}$ (ref. 1). However, very few studies on litter decomposition have been made in temperate Russian forest ecosystems in order to understand the turnover of carbon and other nutrients in these sensitive ecosystems.

In soils of forest ecosystems, the rate of litter decomposition is determined by a number of biophysical, chemical and biological factors including humidity, temperature, $\mathrm{pH}$, nitrogen and oxygen, and composition of the microbial population. Soil moisture is one of the main factors determining the activity of soil microbial communities and, accordingly, regulating the processes and rates of destruction. It was found that insufficient (below 30\%) or excessive (above 150\%) moisture level significantly inhibited the rate of decomposition of cellulose ${ }^{2}$.

Another important abiotic force affecting the destructive microbial activity is temperature, which can be considered as a prime factor in determining the rates of litter decomposition $^{3}$, and decomposition was found to be more sensitive to temperature than primary production ${ }^{4}$. The effect of temperature is primarily due to its influence on the growth and activity of soil organisms, as well as on saturation of the soil with oxygen and soluble nutrients. The literature shows that the optimal temperature for cellulose decomposition in the soil is $35-37^{\circ} \mathrm{C}$, although decomposition can occur at lower temperatures of $0-5^{\circ} \mathrm{C}$ (ref. 2). Temperature was also reported to affect the intensity and rate of mineralization of plant residues six times more than humidity ${ }^{5}$. Numerous reviews on the role of microbes in the litter degradation process are availa$b^{6-8}$. Microbial litter decomposition proceeds through 
different mechanisms, especially heterotrophic consumption of organic composites and $\mathrm{CO}_{2}$ release which can add more than $20 \%$ to soil surface $\mathrm{CO}_{2}$ efflux; this is known as soil respiration.

Microbial decomposition of litter can be divided into phases, in each of which specific products are formed, making it possible to develop certain groups of microorganisms. The initial stages of decomposition are dominated by the release (mainly by leaching) of $\mathrm{Ca}, \mathrm{K}$ and $\mathrm{Mg}$, while for $\mathrm{N}, \mathrm{P}$ and $\mathrm{S}$ there may be a temporary increase in their content in plant residues. Intermediate decay products are the nutrient substrates for different populations supporting the diversity of soil microbiota and its succession changes during decomposition ${ }^{9}$. The interaction of different representatives of the biodegradation block in soils is an important factor determining the intensity of plant litter decomposition ${ }^{10}$. The rate of decomposition of nutrient-rich litter at the initial stage is higher than that of nutrient-pure litter, but the situation may reverse in the later stages.

Temperature changes affect not only the activity, but also the composition of microbial hydrolytic communities $^{11}$. Effective decomposition of lignin in soils is carried out by several groups of fungi ${ }^{12}$. Gram-positive bacteria are adapted to soils with a low content of available substrates and Gram-negative bacteria are more dependent on the supply of fresh organic matter, forming 'hot spots' of decomposition of organic matter (OM) in the soil ${ }^{13}$. It was found that changes in soil temperature ${ }^{14}$ and changes in the composition of $\mathrm{OM}^{15,16}$ cause structural changes in the composition of these microbial groups. Thus, the study of temperature control of fungal and bacterial communities involved in the decomposition of OM, as well as the monitoring of microbial successions under global climate change are of environmental importance.

According to modern climate models, the 21 st century will be characterized by a global increase in air temperature $^{17,18}$. For regions of middle and high latitudes, as well as Polar Regions, the temperature is projected to increase by $3-5^{\circ} \mathrm{C}$ (ref. 19). Temperature rise can increase the flow of organic residues into the soil, and also increase the rate of microbial decomposition. The long-term effects of global warming on soil organic matter (SOM) are not yet fully understood ${ }^{20,21}$. According to some estimates, after a short burst of mineralization affecting a small active (labile) pool of organic matter, the process will slow down. Other studies predict no significant changes or even an increase due to mineralization of a large stable pool with great thermal sensitivity.

This study was undertaken to analyse the temperature sensitivity of litter decomposition, as well as activity, number and composition of microbial communities in forest soil. It is hypothesized that temperature change is the main driver of microbial activity and differentiation of microbial communities at the initial stage of transformation of tree litter. To test this hypothesis, a series of incubation experiments were carried out under controlled temperature conditions with aerobic soil microcosms of the mixed forest amended with fragments of aspen leaves and twigs.

\section{Materials and methods}

Soil samples were selected in June 2017 from a depth of $0-20 \mathrm{~cm}$ in the secondary forest near Pushchino town, Moscow region $\left(54.8^{\circ} \mathrm{N} ; 37.6^{\circ} \mathrm{E}\right)$. The tree vegetation was represented by aspen (Populus tremola), Norway maple (Acer platanoides), birch (Betula sp.) and alder (Alnus). The soil was defined as grey forest loamy on top loam, underlain by moraine (Gleyic Phaeozem) and is typical of the southern Moscow region. The $\mathrm{pH}$ value of the aqueous suspension was 5.28 and organic carbon content was $2.53 \%$. The mineral nitrogen content (ammonium and nitrate) was similar and amounted to $1.48 \mathrm{mg} \mathrm{N}$ per $100 \mathrm{~g}$ of soil. Incubation experiments with aerobic microcosms were carried out in $100 \mathrm{ml}$ glass bottles, with $10 \mathrm{~g}$ fresh soil six-fold repetition. Microcosms were incubated for 28 days in thermostats at three temperature regimes: $5^{\circ} \mathrm{C}$ (model of average temperature for spring and autumn months in the southern Moscow region), $15^{\circ} \mathrm{C}$ (model of average temperature in summer) and $25^{\circ} \mathrm{C}$ (model of global temperature rise). To clarify the agents of transformation of plant residues in the soil, fragments of fallen aspen leaves and twigs $(<0.5 \mathrm{~mm})$ were added at $0.5 \%$ by weight. The content of total organic carbon and total nitrogen in plant materials was measured with an elemental analyser (Leco CHNS-932, USA). Carbon content in the leaves was $42.853 \pm 0.580 \%$, nitrogen content was $0.923 \pm 0.023 \%$, and $\mathrm{C}: \mathrm{N}$ ratio was 46.45 . For the twigs, these values were $46.540 \pm 0.447 \%, 0.738 \pm 0.29 \%$ and 63.08 respectively.

During the incubation period, soil samples were maintained at a constant moisture content of $25 \%$ by weight (60\% water holding capacity (WHC). Half of the microcosms was used to quantify $\mathrm{CO}_{2}$ emission and the rest was used for chemical and molecular analyses. The biological activity of soils was assessed by the intensity of $\mathrm{CO}_{2}$ emission using gas chromatography. Measurements were done on Crystal-5000 (JSC SCB Chromatek, Russia) after $24-48 \mathrm{~h}$ of incubation. To assess the respiratory response to temperature changes and litter addition, the delta respiration values in samples with leaves $\left(\mathrm{DR}_{\mathrm{L}}\right)$ and twigs $\left(\mathrm{DR}_{\mathrm{T}}\right)$ were calculated as the integral $\mathrm{CO}_{2}$ accumulation minus control values.

The dynamics of substrate decomposition was estimated as the difference between the integral accumulation of $\mathrm{C}-\mathrm{CO}_{2}$ in the variants of experiment with the addition of plant material and the control without application. The rate of decomposition of substrates was calculated using the formula

$$
L_{\mathrm{t}}=L_{0} \times \mathrm{e}^{-k t},
$$


where $L_{\mathrm{t}}$ is the mass of the substrate at time $t(\mathrm{mg} \mathrm{C}), L_{0}$ the mass of the substrate at zero point $(\mathrm{mg} \mathrm{C}), k$ a characteristic of the rate of substrate decomposition and $t$ is the incubation time (days).

The temperature sensitivity was characterized by a temperature coefficient $\left(Q_{10}\right)$, which shows how the intensity of $\mathrm{CO}_{2}$ emission increases with increase in the incubation temperature at $10^{\circ} \mathrm{C} . Q_{10}$ was calculated using the formula

$$
Q_{10}=\left(K_{2} / K_{1}\right)^{\left[\left(10 /\left(T_{2}-T_{1}\right)\right]\right.},
$$

where $K_{2}$ is the rate of decomposition of the substrate at the higher temperature $T_{2}$ and $K_{1}$ is the rate of decomposition of the substrate at the lower temperature of $T_{1}$.

SOM content was determined in accordance with the technique of Schulte et $a l^{22}$. Soil samples taken at the beginning of incubation and after 28 days were dried to constant weight first at $105^{\circ} \mathrm{C}$ and then at $360^{\circ} \mathrm{C}$. The organic matter content was calculated using the formula

$$
S(\%)=\left(W_{105}-W_{360}\right) / W_{105} \times 100,
$$

where $W_{105}$ and $W_{360}$ are the weights of soil samples dried at $105^{\circ} \mathrm{C}$ and $360^{\circ} \mathrm{C}$ respectively. In order to calculate the $\mathrm{OM}$ content, a conversion factor of 0.58 was used ${ }^{23}$, which corresponds to the average carbon content in humic acid equal to $58 \%$.

The amount of DNA was estimated as a proxy of microbial biomass in soil samples. The allocation of total DNA from fresh samples of the microcosm was performed using commercial reagents kits Fast DNA Spin kit for Soil (MP Biomedicals, Germany) according to the manufacturer's recommendations. DNA content in the solution was determined spectrophotometrically at $260 \mathrm{~nm}$ using (NanoDrop 2000c; Thermo Fisher Scientific, USA). Calculation of DNA content in the soil was carried out taking into account the breeding factor. To recalculate DNA content to the value of microbial biomass corresponding to determination by the substrate-induced respiration method, a conversion factor of 5.1 previously obtained for grey forest soils of the Moscow region was applied $^{24}$.

Quantifications of bacteria, archaea and fungi in soil samples were carried out every week by polymerase chain reaction in real time (qPCR). The qPCR assays were performed in triplicate using B buffer (Syntol, Russia) with SYBR Green I and passive reference dye ROX. Amplification was performed using a thermal cycler (CFX96 Touch ${ }^{\mathrm{TM}}$; Bio-Rad, USA). To calculate the number of phylotypes in natural samples, the signal value in the sample was compared with a standard curve constructed for a series of successive dilutions of a standard sample with known concentration. A standard sample was prepared from the target PCR fragment cloned in the $\mathrm{T}$ vector (Promega, USA). Fragments of ribosomal operon of 16S DNA Esherichia coli (bacteria) and archaea Methanosarcina barkerii (archea) and 18S DNA Penicillium chrysogenum (fungi) were used as standards. The number of copies per gram of soil was calculated taking into account the initial sample and manipulations with the DNA preparation isolated from the soil. Despite the fact that the number of ribosomal operons in the genomes of microorganisms varies widely, it was found that when recalculated by the average values number were close to the real indicators ${ }^{25}$. We used per cent proportion of fungi relative to bacteria as it provides a better picture of the differences with lesser decimal points than the absolute $\mathrm{F}: \mathrm{B}$ ratio. It was calculated using the formula

$$
\% \text { Proportion } \mathrm{F}: \mathrm{B}=\frac{\text { Fungal copy number }}{\text { Bacterial copy number }} \times 100 \text {. }
$$

Statistical data processing and graphical representation of the obtained results were carried out using Microsoft EXCEL.

\section{Results and discussion}

Litter decomposition in forest ecosystems plays an important role in the global carbon cycle through nutrient recycling and $\mathrm{CO}_{2}$ emissions to the atmosphere. Several methods are used to study litter decomposition. The litter bag method, based on the determination of loss of litter mass in meshed bags placed on the soil surface or in the topsoil, is widely applied in ecological studies. However, the aim of this study is to understand the impact of temperature on the biological mechanisms (microbial activity and composition) of litter break-down, so the incubation experiments were chosen. Laboratory incubation experiment is the most unbiased method to study soil processes and underlying mechanisms because it can isolate the effects of a single process on system dynamics.

Evaluation of $\mathrm{CO}_{2}$ emission intensity (Figure 1) demonstrated clear differences in the dynamics and activity of basal and substrate-induced oil respiration for experiments under different temperatures. When incubated at $5^{\circ} \mathrm{C}$, the magnitude of basal respiration was low during the entire observation period and a significant increase after the addition of substrates was recorded only 8-10 days after the start of incubation (Figure 1). In variants of $15^{\circ} \mathrm{C}$ and $25^{\circ} \mathrm{C}$, the intensity of basal respiration was significantly higher, it increased immediately at the beginning of incubation and reached a maximum value after 8-10 days. Within 2-3 days there was significant increase in comparison with the control of respiratory activity induced by the introduced substrates. A similar character of the dynamics of respiratory activity induced by substrates was described earlier by other research$\mathrm{ers}^{26,27}$. The rate of respiratory $\mathrm{C}$ loss was highest 

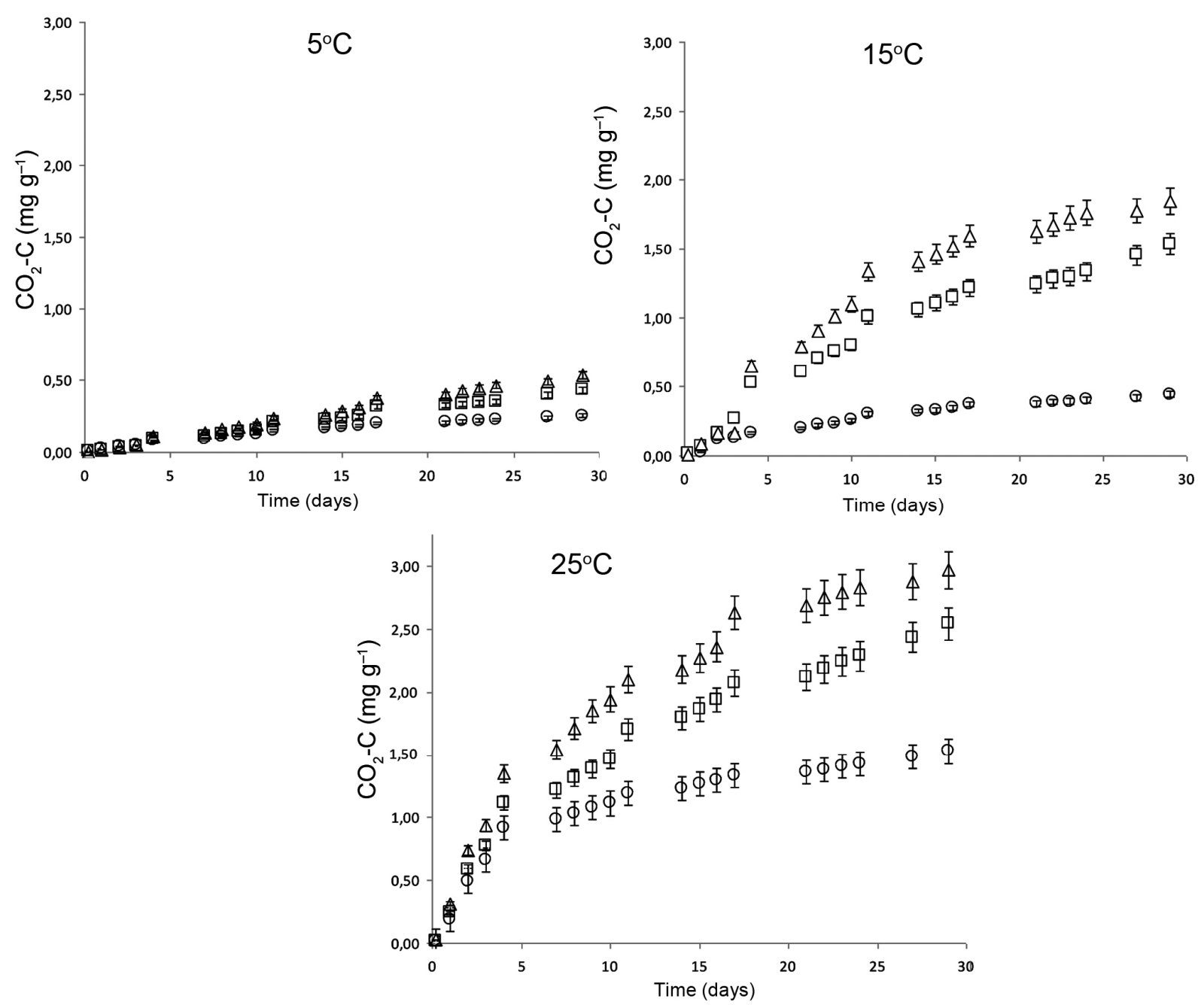

Figure 1. Dynamics of cumulative emission of $\mathrm{CO}_{2}-\mathrm{C}$ from soil samples incubated at different temperatures.

Table 1. Influence of incubation temperature on the respiration response of microbial community to substrate addition and decomposition rate of litter

\begin{tabular}{lccccc}
\hline & \multicolumn{2}{c}{$\begin{array}{c}\text { Delta respiration } \\
\left(\mathrm{mg} \mathrm{CO}_{2}-\mathrm{C} \mathrm{g}^{-1} \text { soil dry wt for } 28 \text { days }\right)\end{array}$} & & \multicolumn{2}{c}{$\begin{array}{c}\text { Rate of litter decomposition } \\
\left(\mathrm{mg} \mathrm{C} \mathrm{g}^{-1} \text { day }^{-1}\right)\end{array}$} \\
\cline { 2 - 3 } \cline { 6 - 7 } Temperature $\left({ }^{\circ} \mathrm{C}\right)$ & $\mathrm{DR}_{\mathrm{L}}$ & $\mathrm{DR}_{\mathrm{T}}$ & & Leaves & Twigs \\
\hline 5 & 2.11 & 1.71 & & 0.24 & 0.16 \\
15 & 4.15 & 3.45 & & 1.11 & 0.83 \\
25 & 1.94 & 1.66 & & 1.22 & 0.83 \\
\hline
\end{tabular}

between 4 and 14 days, and returned to practically the basal level in 28 days after litter application. This suggests that most part of the substrate had degraded within the experimental period; similar decomposition dynamics has been reported by other researchers ${ }^{26}$.

The greatest response of the soil microbial community to substrate application was recorded in experiment under $15^{\circ} \mathrm{C}$ temperature (Table 1). Addition of leaf fragments increased respiratory activity $\left(\mathrm{DR}_{\mathrm{L}}\right)$ up to 4.15 times, and twigs addition $\left(\mathrm{DR}_{\mathrm{T}}\right)$ up to 3.45 times. For both low and high temperatures the values of the coefficients were approximately two times lower.

The dynamics of decomposition of the introduced substrates was studied as the difference between the integral accumulation of $\mathrm{C}-\mathrm{CO}_{2}$ in experiments with substrate application and the control. At the low temperature $5^{\circ} \mathrm{C}$, a 

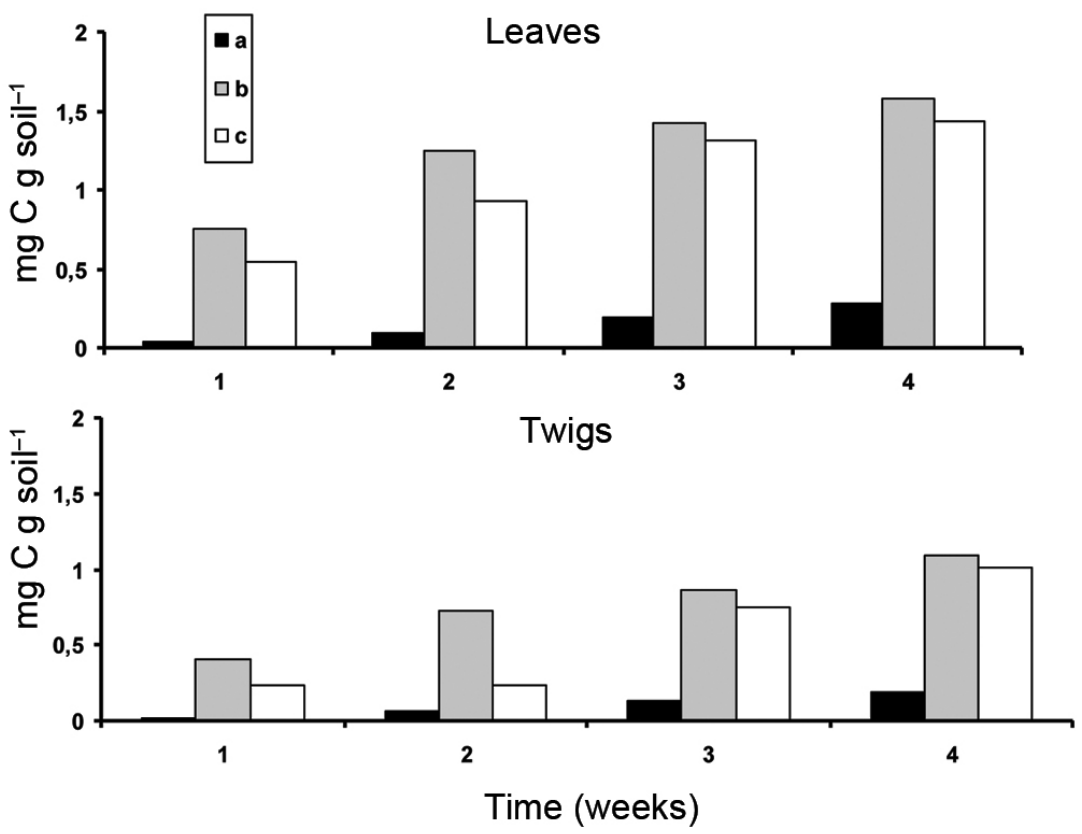

Figure 2. Temperature effect on decomposition of the aspen leaf and twig litter in soil incubation experiments: $\boldsymbol{a}, 5^{\circ} \mathrm{C} ; \boldsymbol{b}, 15^{\circ} \mathrm{C} ; \boldsymbol{c}, 25^{\circ} \mathrm{C}$.

Table 2. Temperature sensitivity of microbial processes in forest soil

\begin{tabular}{lcc}
\hline Variants & \multicolumn{2}{c}{ Temperature coefficient $\left(Q_{10}\right)$} \\
\hline Temperature interval $\left({ }^{\circ} \mathrm{C}\right)$ & $5-15$ & $5-25$ \\
Basal respiration & 1.75 & 3.44 \\
Decomposition of leaves & 3.44 & 1.61 \\
Decomposition of twigs & 3.54 & 1.65 \\
\hline
\end{tabular}

uniform decrease in carbon content of the deposited substrates was observed throughout the observation period (Figure 2). For 28 days, C loss was $0.28 \mathrm{mg}(6.8 \%$ of the initial content) for leaves and $0.1 \mathrm{mg}(4.16 \%)$ for twigs. In the variants of $15^{\circ} \mathrm{V}$ and $25^{\circ} \mathrm{C}, \mathrm{C}$ content decreased intensively during the first two weeks, and then the rate slowed down (Figure 2). The values of leaf litter decomposition were similar at $15^{\circ} \mathrm{C}$ and $25^{\circ} \mathrm{C}$, and reached $1.58 \mathrm{mg}(37 \%)$ and $1.45 \mathrm{mg}(33.9 \%)$ respectively. A similar pattern was obtained for twig litter - the loss by microbial respiration was $1.09 \mathrm{mg} \mathrm{C} \quad(23.49 \%)$ and $1.02 \mathrm{mg} \mathrm{C}(21.81 \%)$. The average rate of decay of leaves and twigs over the experimental period was lowest at $5^{\circ} \mathrm{C}$, and increased significantly with rise in temperature (Table 2).

Despite the fact that the absolute values of cumulative respiratory activity in the variants of $15^{\circ} \mathrm{C}$ and $25^{\circ} \mathrm{C}$ differed significantly, the amount of completely oxidized substrate was similar. The cumulative amount of $\mathrm{C}-\mathrm{CO}_{2}$ emitted during the incubation period from soil samples with leaves and twigs at $15^{\circ} \mathrm{C}$ was 18.47 and $15.34 \mathrm{mg}$ respectively, while at $25^{\circ} \mathrm{C}$ these values were $29.71 \mathrm{mg}$ and $24.45 \mathrm{mg}$ respectively. Thus, an increase in temperature leads to a change in the ratio of carbon of fresh plant material and SOM in the $\mathrm{CO}_{2}$ emission pool towards an increase in the proportion of soil carbon (so-called priming effect).

To compare SOC mineralization under different temperatures, the percentage of SOM mineralized ( $\%$ SOC) was calculated. It was found that the litter and control treatments were not significantly different for SOC mineralization at $5^{\circ} \mathrm{C}$, and it was about $0.8 \%-0.9 \%$. The amount of mineralized carbon significantly increased with temperature for all the variants, but varied for different temperature ranges. At $25^{\circ} \mathrm{C}$, it increased up to $5.2 \%$ for the control and $6.5 \%$ and $7.2 \%$ for leaves and twigs respectively.

Confirmation of this assumption requires additional research, in particular with the use of radioactively labelled plant substrates, which will allow us to accurately assess the carbon distribution. Our findings are in agreement with the results of other studies ${ }^{26}$. In the study of arable Chernozem soils in Germany with ${ }^{13} \mathrm{C}$-labelled plant residues, the greatest contribution of fresh plant matter to respiratory activity of the soil was found in the few first days after application, and then its share decreased, especially in conditions of elevated temperature ${ }^{26}$.

The principles of chemical kinetics suggest that temperature sensitivity of the process depends on the quality of the substrate, and it can be assumed that the processes in which the share of SOM is higher than fresh organic substrates, should be more sensitive to temperature. SOM consists of complex organic molecules and their decomposition requires high energy expenditure activation. Therefore, an increase in temperature will have a greater impact on the dynamics of these components ${ }^{28}$. 


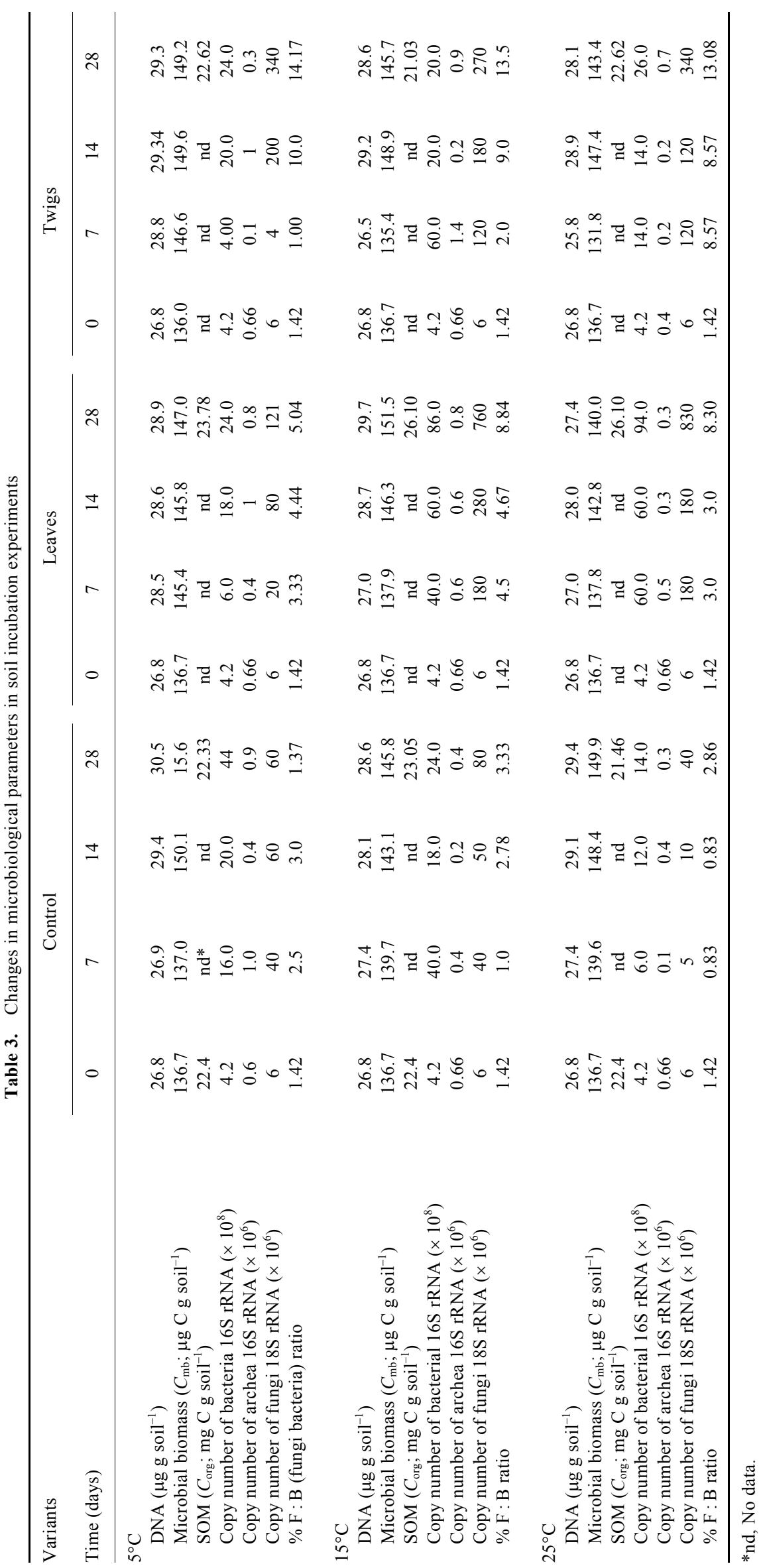


The temperature sensitivity of substrate decomposition rate was characterized by a temperature coefficient $\left(Q_{10}\right)$. For basal respiration, the main substrate of which is SOM, $Q_{10}$ for the temperature range $5-15^{\circ} \mathrm{C}$ was 1.75 , and with rising temperature in the range $15-25^{\circ} \mathrm{C}$, it increased to 3.4. At the same time, in variants with the introduction of fresh organic matter, both leafs and twigs, the reverse pattern was observed - high coefficient value at low temperatures, which decreased at high temperatures (Table 2). The obtained values of temperature coefficients were close to the $Q_{10}$ values obtained at the initial stages of leaf litter decomposition in model experiments with sand microcosms ${ }^{29}$.

Soil microorganisms are an integral part of forest ecosystems and play a critical role in the decomposition of organic matter and the immobilization and mineralization of nutrients. Quantitative characteristics of microbial biomass is one of the main parameters which reflects the increase in microbial activity, and is used as an important ecological indicator for the decomposition and mineralization of plant residues in the soil ${ }^{30}$. Microbial biomass slightly increased on litter addition, but remained uniform throughout the experimental period under all temperature regimes (Table 3). During the entire observation period, microbial biomass varied in the range from $136 \mu \mathrm{g} \mathrm{g}^{-1}$ to $150 \mu \mathrm{g} \mathrm{g}^{-1}$ for all experimental variants. A possible reason for this may be the lack of nitrogen available to microbial growth. The ratio of $\mathrm{C}: \mathrm{N}$ in the leaves was 46.45 , and in twigs 63.08. Another possible explanation may be that the introduced substrates were used only for the transition of resting forms of soil microorganisms to their active state and further maintenance of their hydrolytic activity.

The share of microbial biomass carbon in the gross, SOM content $\left(\mathrm{C}_{\mathrm{MIC}}: \mathrm{C}_{\mathrm{ORG}}\right)$ is an important ecological and physiological parameter of the microbial community, reflecting its trophic level ${ }^{30}$. The $\mathrm{C}_{\mathrm{MIC}}: \mathrm{C}_{\mathrm{ORG}}$ ratio is also an indicator of the availability of soil carbon for microorganisms, and the narrowing of this ratio in the soil indicates stability of the organic substrate or the presence of conditions that prevent the development of microorganisms ${ }^{31}$. The introduction of leaf litter led to an increase in the SOM content, which was especially evident in the experiments at $15^{\circ} \mathrm{C}$ and $25^{\circ} \mathrm{C}$; however, the carbon fraction of microbial biomass remained constant and varied between $0.5 \%$ and $0.6 \%$ of the organic carbon content.

Methods of molecular biology were applied to obtain quantitative data of microorganisms in the process of primary stage transformation of litter in the soil. Using qPCR, the dynamics of copy number of ribosomal genes was studied (Table 3 ). The number of bacterial copies of 16s rRNA ranged from $4 \times 10^{8}$ to $9 \times 10^{9}$ per $\mathrm{g}$ of soil. Incubation with leaves and twigs led to an increase in the number of bacteria by not more than 2-7 times compared to the control. The number of fungi copies of $18 \mathrm{~s}$ rRNA ranged from 6 to $340 \times 10^{6}$ per $g$ of soil, and increased in variants with the introduction of substrates by 2-5 times.
The number of archaea did not change significantly and was $0.3-0.7 \times 10^{6}$ per $g$ of soil. The data obtained are consistent with the results of the determination of microbial biomass and indicate that in the primary stages of decomposition of fresh plant material, there is an increase in the activity of hydrolytic microorganisms, but there is no significant increase in number.

One of the approaches to understand the functioning of microbial soil communities is their differentiation into ecologically significant groups, e.g. copiotrophs and oligotrophs, autochthonous and zymogenous, r- and kstrategies, as well as eukaryotes (fungi) and prokaryotes (bacteria) ${ }^{32}$. A widely considered proxy microbial indicator is based on the sub-division of microbes into major decomposer groups, namely fungi and bacteria, indexed as the $\mathrm{F}: \mathrm{B}$ ratio. This has been extensively used in soil ecology, particularly in the context of land management and its effects on soil carbon sequestration. Quantitative PCR (qPCR) approaches are increasingly being used to measure the $\mathrm{F}: \mathrm{B}$ ratio which reflects the processes of decomposition of substrates, transformation of nutrients and the ability of soil ecosystems to self-regulate ${ }^{33}$. The per cent proportion of fungi relative to bacteria in soil microbial community increases after litter addition under all temperature regimes (Table 3). Despite bacteria being most dominant in the studied soil system, their fungal abundance was increased after litter addition. Increased fungal abundance may largely be a reflection of shifts in abundance of hydrolytic fungi.

\section{Conclusion}

In incubation experiments with soil samples, it was found that at the initial stages of decomposition of fresh leaf and twig litter, the process is characterized by high sensitivity to temperature. Microbial decomposition of introduced residues was most intense during the first 3-5 days of incubation, possibly due to the use of water-soluble organic compounds. It was found that the efficiency of the substrates was largely dependent on temperature. Also, the temperature of $15^{\circ} \mathrm{C}$, corresponding to the average temperature during summer months, was optimal for microbial degradation of leaf and tree litter in grey forest soil, while a decrease or increase in temperature led to a decrease in the intensity of decomposition of plant material. RNA-based approaches were used to identify the microbial decomposers involved in litter degradation, and provide information on active organisms. Therefore, it was possible to monitor time-dependent shifts. The F : B ratio increased on addition of both leaf and twig litter at all temperature regimes, implicating fungal decomposers in substrate use.

1. Basilevich, N. I., Biological Productivity of Ecosystem in the North Eurasia, Nauka, Moscow, 1993, p. 293 (in Russian). 
2. Clein, J. S. and Schimel, J. P., Microbial activity of tundra and taiga soils at sub-zero temperatures. Soil Biol. Biochem., 1995, 27, 1231-1234.

3. Hobbie, S. E., Temperature and plant species control over litter decomposition in Alaskan tundra. Ecol. Monogr., 1996, 66, 503522 .

4. Kirschbaum, M. U. F., Will changes in soil organic carbon act as a positive or negative feedback on global warming? Biogeochemistry, 2000, 48, 21-51.

5. Schlesinger, W. H., Soil organic matter: a source of atmospheric $\mathrm{CO}_{2}$. In The Role of Terrestrial Vegetation in the Global Carbon Cycle: Measurement by Remote Sensing (Scope 23) (ed. Woodwell, G. M.), John Wiley, London, UK, 1984, pp. 111-127.

6. Ball, A. S., Microbial decomposition at elevated $\mathrm{CO}_{2}$ levels: effect of litter quality. Global Change Biol., 1997, 3, 379-386.

7. Berg, B. and McClaugherty, C., Plant litter decomposition humus formation. In Carbon Sequestration, Springer, Berlin, Germany, 2003, p. 296.

8. Krishna, M. P. and Mohan, M., Litter decomposition in forest ecosystems: a review. Energ. Ecol. Environ., 2017, 2, 236-249.

9. Berg, B. and McClaugherty, C., Plant Litter-Decomposition, Humus Formation, Carbon Sequestration, Springer-Verlag, Berlin, Germany, 2008, p. 315.

10. Rakhleeva, A. A., Semenova, T. A., Striganova, B. R. and Terekhova,. V. A., Dynamics of zoomicrobial complexes upon decomposition of plant litter in spruce forests of the southern taiga. Euras. Soil Sci., 2011, 44, 38-48.

11. Matzner, E. and Borken, W., Do freeze - thaw events enhance C and $\mathrm{N}$ losses from soils of different ecosystems? A review. Europ. J. Soil Sci., 2008, 59, 274-284.

12. Carlile, M., Watkinson, S. and Gooday, G., The Fungi, Academic Press, London, UK, 2001, 2nd edn, p. 608.

13. Kramer, C. and Leixner, G. G., Variable use of plant- and soilderived carbon by microorganisms in agricultural soils. Soil Biol. Biochem., 2006, 38, 3267-3278.

14. Pettersson, M. and Baath, E., Temperature-dependent changes in the soil bacterial community in limed and unlimed soil. FEMS Microbiol. Ecol., 2003, 45, 13-21.

15. Carney, K., Hungate, B., Drake, Sb. and Megonigal, J., Altered soil microbial community at elevated $\mathrm{CO}_{2}$ leads to loss of soil carbon. Proc. Acad. Sci. USA, 2007, 104, 4990-4995.

16. Treseder, K. K., Nitrogen additions and microbial biomass: a meta-analysis of ecosystem studies. Ecol. Lett., 2008, 11, 1111-1120.

17. Cox, P. M., Betts, R. A., Jones, C. D., Spall, S. A. and Totterdell, I. J., Acceleration of global warming due to carbon-cycle feedbacks in a coupled climate model. Nature, 2000, 408, 184-187.

18. Meehl, G. A. et al., Climate Change 2007: The Physical Science Basis. In Contribution of Working Group I to the Fourth Assessment Report of the Intergovernmental Panel on Climate Change, Cambridge University Press Cambridge, UK and NY, USA, 2007

19. Christensen, J. H. et al., Regional climate projections. In Climate Change 2007: The Physical Science Basis. In Contribution of Working Group I to the Fourth Assessment Report of the Intergovernmental Panel on Climate Change, Cambridge University Press, Cambridge, UK, 2007.

20. Kirschbaum, M. U. F., The temperature dependence of organicmatter decomposition - still a topic of debate. Soil Biol. Biochem., 2006, 38, 2510-2518.
21. Hartley, I. P. and Vinson, P., Substrate quality and the temperature sensitivity of soil organic matter decomposition. Soil Biol. Biochem., 2008, 40, 1567-1574.

22. Schulte, E. E., Kaufmann, C. and Peter, J. B., The influence of sample size and heating time on soil weight loss-on-ignition. Commun. Soil Sci. Plant Anal., 1991, 22, 159-168.

23. Orlov, D. S., Humic Substances of Soils and General Theory of Humification, Oxford \& IBH Publishing Co Pvt Ltd, New Delhi, India, 1995, p. 323.

24. Semenov, M., Blagodatskaya, E., Stepanov, A. and Kuzyakov, Y., DNA-based determination of soil microbial biomass in alkaline and carbonaceous soils of semi-arid climate. J. Arid. Environ., 2018, 150, 54-61.

25. Andronov, E. E. et al., Analysis of the structure of microbial community in soils with different degrees of salinization using T-RFLP and real-time PCR techniques. Euras. Soil Sci., 2012, 45, 147-156.

26. Thiessen, S., Gleixner, G., Wutzler, T. and Reichstein, M., Both priming and temperature sensitivity of soil organic matter decomposition depend on microbial biomass - an incubation study. Soil Biol. Biochem., 2013, 57, 739-748.

27. Malik, Z. A., Pandey, R. and Bhatt, A. B., Anthropogenic disturbances and their impact on vegetation in Western Himalaya, India. J. Mt. Sci., 2016, 13, 69-82.

28. Yuste, J. C., Baldocchi, D. D., Gershenson, A., Goldstein, A., Misson, L. and Wong, S., Microbial soil respiration and its dependency on carbon inputs, soil temperature and moisture. Global Change Biol., 2007, 13, 2018-2035.

29. Kaiser, E.-A. and Heinemeyer, O., Seasonal variations of soil microbial biomass carbon within the plough layer. Soil Biol. Biochem., 1993, 25, 1649-1655.

30. Marinari, S., Mancinelli, R., Campiglia, E. and Grego, S., Chemical and biological indicators of soil quality in organic and conventional farming systems in Central Italy. Ecol. Indic., 2006, 6, 701-711.

31. Semenov, V. M., Kogut, B. M., Zinyakova, N. B., Masyutenko, N. P., Malyukov, L. S., Lebedeva, T. N. and Tulina, A. S., Biologically active organic matter in soils of European Russia. Euras. Soil Sci., 2018, 51, 434-447.

32. Strickland, M. S. and Rousk, J., Considering fungal : bacterial dominance in soils - methods, controls, and ecosystem implications. Soil Biol. Biochem., 2010, 42, 1385-1395.

33. van der Heijden, M. G. A., Bardgett, R. D. and Van Straalen, N. M., The unseen majority: soil microbes as drivers of plant diversity and productivity in terrestrial ecosystems. Ecol. Lett., 2008, 11, 296-310.

ACKNOWLEDGEMENTS. This research was funded by the Russian Ministry of Science and Higher Education and also has been supported by RFBR under research project no. 18-54-53004. We thank Dr Tatyana Kuznetsova and Dr Sergey Udaltsov for assistance in the field and laboratory.

Received 23 August 2018; revised accepted 20 November 2018

doi: $10.18520 / \mathrm{cs} / \mathrm{v} 116 / \mathrm{i} 5 / 765-772$ 